\title{
Zinc Finger CCCH Domain-Containing Protein 11A
}

National Cancer Institute

\section{Source}

National Cancer Institute. Zinc Finger CCCH Domain-Containing Protein 11A. NCI

Thesaurus. Code C118348.

Zinc fing er CCCH domain-containing protein 11A (810 aa, $89 \mathrm{kDa}$ ) is encoded by the human $\mathrm{ZC} 3 \mathrm{H} 11 \mathrm{~A}$ gene. This protein plays a role in mRNA export. 